\title{
PELAYANAN PANTI WERDHA TERHADAP ADAPTASI LANSIA
}

\author{
Ari Afriansyah ${ }^{1}$ dan Meilanny Budiarti Santoso ${ }^{2}$ \\ ariafriansyah1998@gmail.com ${ }^{1}$ dan meilannybudiarti13@gmail.com² \\ Fakultas Ilmu Sosial dan Ilmu Politik Universitas Padjadjaran
}

\begin{abstract}
Abstrak
Jumlah lansia di Indonesia mengalami peningkatan secara konsisten setiap tahunnya. Meski demikian tidak semua lansia beruntung bisa tinggal bersama keluarga di masa tuanya, hal itu bisa disebabkan oleh bermacam hal sehingga lansia ditempatkan di tempat penitipan lanjut usia atau biasa disebut dengan panti werdha. Panti werdha merupakan bentuk perhatian yang diberikan oleh pemerintah kepada lansia yang berfungsi untuk menampung lansia di Indonesia. Namun, kehidupan lansia di Panti Werdha tidak semuanya berjalan dengan lancar, tercatat menurut penelitian yang pernah dilakukan di Panti Griya Sehat Bahagia Palur Karanganyar bahwa sebanyak 94,5\% lansia mengalami depresi di Panti karena berbagai hal. Oleh karena itu sudah menjadi tugas panti untuk memberikan pelayanan-pelayanan bagi lansia untuk membantu proses adaptasi lansia dengan memenuhi syarat dasar melangsungkan kehidupan mereka (syarat fisik, kejiwaan dan sosial). Penelitian ini menggunakan metode studi literatur, dimana penulis melakukan kajian terhadap berbagai sumber tertulis, baik berupa buku-buku, arsip, majalah, artikel, dan jurnal, atau dokumen-dokumen yang relevan dengan permasalahan yang dikaji. Dan dari kajian yang telah dilakukan ditemukan bahwa upaya pelayanan lansia telah diatur dalam undang-undang nomor 13 tahun 1998 pasal 3 yang menyatakan bahwa upaya meningkatkan kesejahteraan sosial lanjut usia meliputi pelaksanaan pelayanan bimbingan fisik, pelayanan bimbingan keagamaan/ mental spiritual, pelayanan bimbingan sosial serta bimbingan keterampilan dan telah mencakup segala aspek yang dibutuhkan lansia untuk memenuhi aspek yang diperlukan untuk beradaptasi.
\end{abstract}

Kata Kunci : Lansia, Adaptasi, Panti Werdha, Pelayanan Panti Werdha.

\section{Abstract}

Numbers of elderly people in Indonesia has increased consistently. However, not all elderly people are fortunate to be able to live with their families in their old age, this can be caused by a variety of things so that the elderly are placed in a nursing home. Nursing homes are a attention given by the government to the elderly. However, the lives of the elderly in the Nursing Home didn't all go smoothly, according to a study conducted at the Griya Sehat Bahagia Nursing Home that $94.5 \%$ of the elderly had depression. Therefore it has become the duty of the orphanage to provide services for the elderly to assist the process of adaptation of the elderly by fulfilling the basic requirements for carrying out their lives (physical, psychological and social conditions). This study uses the literature study method. And from the studies, it was found that the service efforts of the elderly have been regulated in law number 13 (1998) article 3 which states that efforts to improve elderly social welfare include the implementation of physical, mental, skill and social guidance services. It all includes all aspects needed by the elderly to fulfill the aspects needed to adapt.

Key Words : Elderly, Adapt, Nursing Home, Nursing Home Services.

\section{PENDAHULUAN}

Manusia merupakan makhluk yang secara sosial memiliki mobilitas tinggi. Sedari kecil hingga tua kita tidak hidup hanya di satu tempat. Dan saat berpindah tempat dari satu tempat ke tempat lain, tentu kita juga akan bertemu dengan suasana yang baru, wajah-wajah baru, bahkan kepribadian yang lebih beragam lagi. Untuk bisa menyesuaikan dengan lingkungan yang baru, kita perlu melakukan beberapa hal agar tidak kesulitan berbaur dilingkungan yang baru. Oleh karena itu dalam proses kehidupan manusia selalu dibutuhkan adaptasi.
Adaptasi/penyesuaian diri adalah mengubah diri sesuai dengan keadaan lingkungan tetapi juga mengubah lingkungan sesuai dengan keadaan (keinginan diri). Mengubah diri sesuai dengan keadaan lingkungan sifatnya pasif (autoplastik). Sebaliknya, apabila individu berusaha untuk mengubah lingkungan sesuai dengan keinginan sendiri sifatnya adalah aktif (alloplastis).

Menurut Gerungan (1996:55) adaptasi
merupakan suatu proses untuk mencapai
keseimbangan dengan lingkungan.

Konsep adaptasi berhubungan dengan mekanisme penanggulangan masalah yang 
dilakukan manusia untuk memenuhi kebutuhan hidup dalam lingkungannya. Karena itu istilah adaptif dikaitkan dengan kemampuan penyesuaian diri manusia di dalam suatu lingkungan baru, tingkah laku adaptif harus dihubungkan dengan respon-respon yang sesuai dengan presden, yang dimiliki dan dipilih oleh seseorang dalam pengambilan keputusan. Tingkah laku adaptif dapat diketahui dari proses adaptif individu dan kelompok individu, baik berkaitan dengan masalah lama maupun baru, tanpa disertai perasaan cemas. (Susanto 1985: 23)

Menurut Suparlan adaptasi itu sendiri pada hakekatnya adalah suatu proses untuk memenuhi syarat-syarat dasar untuk tetap melangsungkan kehidupan. Syarat-syarat dasar tersebut mencakup:

1. Syarat dasar alamiah-biologi (manusia harus makan dan minum untuk menjaga kesetabilan tempratur tubuhnya agar tetap berfungsi dalam hubungan harmonis secara menyeluruh dengan tubuh lainnya).

2. Syarat dasar kejiwaan (manusia membutuhkan perasaan tenang yang jauh dari perasaan takut, keterpencilan gelisah).

3. Syarat dasar sosial (manusia membutuhkan hubungan untuk dapat melangsungkan keturun, tidak merasa dikucilkan, dapat belajar mengenai kebudayaannya, untuk dapat mempertahankan diri dari serangan musuh).

Berdasarkan pengertian dan konsep di atas dapat disimpulkan bahwa adaptasi merupakan pertahanan yang didapat sejak lahir atau diperoleh karena belajar dari pengalaman untuk mengatasi masalah dan memenuhi syarat-syarat dasar untuk melangsungkan hidup. Individu atau kelompok dituntut beradaptasi ketika memasuki suatu lingkungan baru, misalnya adalah lansia yang berada di panti werdha.

Lanjut usia menurut UU RI no 13 tahun 1998 adalah mereka yang telah memasuki usia 60 tahun ke atas (Indriana, 2008, h.3). Banyak istilah yang dikenal masyarakat untuk menyebut orang lanjut usia, antara lain lansia yang merupakan singkatan dari lanjut usia. Istilah lain adalah manula yang merupakan singkatan dari manusia lanjut usia. Apapun istilah yang dikenakan pada individu yang telah memasuki usia 60 tahun ke atas tersebut tidak lebih penting dari realitas yang dihadapi oleh kebanyakan individu usia ini. Mereka harus menyesuaikan dengan berbagai perubahan baik yang bersifat fisik, mental, maupun sosial. Perubahanperubahan dalam kehidupan yang harus dihadapi oleh individu usia lanjut khususnya berpotensi menjadi sumber tekanan dalam hidup.
Dalam UU No. 13 tahun 1998 dan Permensos No. 19 tahun 2012, penduduk lansia dikelompokkan dalam 2 kategori yaitu Lanjut Usia Terlantar dan Lanjut Usia Potensial. Lanjut Usia Telantar adalah seseorang yang berusia 60 (enam puluh) tahun atau lebih dan karena faktor-faktor tertentu tidak dapat memenuhi kebutuhan dasarnya; sementara itu Lanjut Usia Potensial adalah penduduk lansia yang masih mampu melakukan pekerjaan dan/atau kegiatan yang dapat menghasilkan barang dan/atau jasa. Penduduk lansia terlantar dianggap sebagai penyandang masalah kesejahteraan sosial (PMKS), karena mereka memiliki kehidupan yang tidak layak secara kemanusiaan dan memiliki kriteria masalah sosial diantaranya kemiskinan dan ketelantaran. Mereka tidak terpenuhi kebutuhan dasarnya seperti sandang, pangan, dan papan; dan terlantar secara psikis, dan sosial (Lampiran Permensos No. 08 Tahun 2012).

Menurut data Badan Pusat Statistik (BPS), dalam waktu hampir lima dekade, persentase lansia Indonesia meningkat sekitar dua kali lipat (19712017), yakni menjadi 8,97 persen (23,4 juta) di mana lansia perempuan sekitar satu persen lebih banyak dibandingkan lansia laki-laki (9,47 persen banding 8,48 persen). Selain itu, lansia Indonesia didominasi oleh kelompok umur 60-69 tahun (lansia muda) yang persentasenya mencapai 5,65 persen dari penduduk Indonesia, sisanya diisi oleh kelompok umur 70-79 tahun (lansia madya) dan 80+ (lansia tua). Pada tahun ini sudah ada lima provinsi yang memiliki struktur penduduk tua di mana penduduk lansianya sudah mencapai 10 persen, yaitu : DI Yogyakarta (13,90 persen), Jawa Tengah (12,46 persen), Jawa Timur (12,16 persen), Bali (10,79 persen) dan Sulawesi Barat (10,37 persen). Pada tahun 2025, jumlah penduduk lansia diproyeksikan akan berjumlah 33,7 juta atau sekitar 11,8\%; dan pada tahun 2035 akan mencapai 48,2 juta atau sekitar $15,8 \%$

Penduduk lanjut usia merupakan bagian dari anggota keluarga dan anggota masyarakat yang semakin bertambah jumlahnya sejalan dengan peningkatan usia harapan hidup. Pada tahun 1980 penduduk lanjut usia baru berjumlah 7,7 juta jiwa atau 5,2 persen dari seluruh jumlah penduduk. Pada tahun 1990 jumlah penduduk lanjut usia meningkat menjadi 11,3 juta orang atau 8,9 persen. Jumlah ini meningkat di seluruh Indonesia menjadi 15,1 juta jiwa pada tahun 2000 atau 7,2 persen dari seluruh penduduk. Diperkirakan pada tahun 2020 akan menjadi 29 juta orang atau 11,4 persen. Hal ini menunjukkan bahwa penduduk lanjut usia meningkat secara konsisten dari waktu ke waktu (Suhartini, 2007).

Oleh karena itu keberadaan panti werdha untuk menampung para lansia di Indonesia merupakan salah satu bentuk perhatian pemerintah 
pada kelompok usia ini. Panti werdha adalah sebutan lain untuk panti jompo dalam bahasa Bali, menunjuk pada wisma dengan fasilitas penunjang yang diperuntukkan bagi orang lanjut usia (lansia). Panti werdha yang di negara Barat disebut dengan retirement home atau old people's home/old age home merupakan tempat tinggal bagi lansia yang lebih banyak dipilih karena tempat ini memungkinkan lansia untuk tetap hidup tanpa menggantungkan diri kepada anak/keluarga. Selain itu juga di panti werdha lansia dapat melakukan aktivitas yang melibatkan aktivitas fisik dan mental.

Oleh karena itu, panti werdha memiliki peranan penting untuk menyediakan berbagai pelayanan bagi lansia guna membantu lansia untuk beradaptasi di “rumah” barunya. Adaptasi lansia di panti werdha merupakan suatu hal yang penting dan dalam proses nya perlu adanya koordinasi dari beberapa pihak terkait untuk saling membantu guna menciptakan lingkungan panti yang nyaman bagi lansia. Hal ini dianggap penting karena kegagalan dalam beradaptasi dapat mengakibatkan dampak buruk bagi lansia itu sendiri, salah satu dampaknya adalah depresi.

Sebuah penelitian pernah diteliti oleh Mahendra Dwi Darmawan dari Universitas Muhammadiyah Surakarta pada tahun 2016 di Panti Griya Sehat Bahagia Palur Karanganyar. Berdasarkan hasil penelitian diketahui 94.5\% lansia mengalami depresi, terbagi dari 41,8\% depresi ringan dan 52,7\% depresi sedang, sedangkan 5,5\% tidak mengalami depresi (normal). Banyak faktor yang melatar belakangi responden mengalami depresi. Berdasarkan hasil penelitian diketahui bahwa responden yang tinggal dipanti banyak karena faktor keluarga. Anggota keluarga baik anak ataupun cucu yang sibuk di dalam pekerjaanya mengakibatkan kurangnya berinteraksi kepada responden. Akibat dari kurangnya interaksi antara responden dengan anggota keluarga adalah kurang terpenuhinya kebutuhan responden dengan baik. Komunikasi yang baik diharapkan oleh responden sering tidak dapat terpenuhi dimana anggota keluarga lebih banyak tidak di rumah dan hanya sedikit waktu untuk dapat berkomunikasi dan dapat memenuhi kebutuhan hidup responden. Meskipun aktivitas fisik masih dapat dilakukan di rumah, namun karena dibatasi oleh anggota keluarga yang merasa khawatir terhadap apa yang dikerjakan responden, maka anggota keluarga menginginkan responden di bawa ke Panti Griya Sehat Bahagia Palur Karanyanyar dengan harapan responden dapat beraktivitas dan terpenuhi kebutuhan hidupnya. Namun persepsi dari 8 anggota keluarga ternyata berbeda kenyataanya dengan apa yang dialami oleh responden. Responden yang telah tinggal di panti ternyata tidak semuanya dalam kondisi normal. Sembilan puluh empat koma lima persen responden ternyata mangalami depresi. Depresi yang dialami responden seperti merasakan kesedihan dikarenakan oleh kehilangan keluarga atau orang yang disayangi. Hawari (2011) menyatakan seseorang yang mengalami depresi mudah merasa haru, sedih, dan menangis. Hal ini merupakan ciri kepribadiaan seseorang yang mengalami depresif.

\section{METODE}

Metode yang digunakan dalam penulisan artikel ini adalah metode studi literatur. Studi literatur yang dilakukan oleh penulis yaitu dengan melakukan pencarian terhadap berbagai sumber tertulis, baik berupa buku-buku, arsip, majalah, artikel, dan jurnal, atau dokumen-dokumen yang relevan dengan permasalahan yang dikaji. Sehingga informasi yang didapat dari studi kepustakaan ini dijadikan rujukan untuk memperkuat argumentasiargumentasi yang ada.

\section{HASIL DAN PEMBAHASAN}

\subsection{Adaptasi}

\section{Definisi Adaptasi}

Adaptasi adalah suatu penyesuaian pribadi terhadap lingkungan, penyesuaian ini dapat berarti mengubah diri pribadi sesuai dengan keadaan lingkungan, juga dapat berarti mengubah lingkungan sesuai dengan keinginan pribadi. Menurut Karta Sapoetra adaptasi mempunyai dua arti. Adaptasi yang pertama disebut penyesuaian diri yang autoplastis (auto artinya sendiri, plastis artinya bentuk), sedangkan pengertian yang kedua penyesuaian diri yang alloplastis (allo artinya yang lain, plastis artinya bentuk). Jadi adaptasi ada yang artinya "pasif" yang mana kegiatan pribadi di tentukan oleh lingkungan. Dan ada yang artinya "aktif" yang mana pribadi mempengaruhi lingkungan

Menurut Suparlan adaptasi itu sendiri pada hakekatnya adalah suatu proses untuk memenuhi syarat-syarat dasar untuk tetap melangsungkan kehidupan. Syarat-syarat dasar tersebut mencakup:

1) Syarat dasar alamiah-biologi (manusia harus makan dan minum untuk menjaga kesetabilan tempratur tubuhnya agar tetap berfungsi dalam hubungan harmonis secara menyeluruh dengan tubuh lainnya).

2) Syarat dasar kejiwaan (manusia membutuhkan perasaan tenang yang jauh dari perasaan takut, keterpencilan gelisah).

3) Syarat dasar sosial (manusia membutuhkan hubungan untuk dapat melangsungkan keturun, tidak merasa dikucilkan, dapat belajar mengenai kebudayaannya, untuk dapat mempertahankan diri dari serangan musuh).

\section{Batasan Pengertian Adaptasi}


Menurut Soerjono Soekanto memberikan beberapa batasan pengertian dari adaptasi, yakni:

1) Proses mengatasi halangan-halangan dari lingkungan.

2) Penyesuaian terhadap norma-norma untuk menyalurkan

3) Proses perubahan untuk menyesuaikan dengan situasi yang berubah.

4) Mengubah agar sesuai dengan kondisi yang diciptakan

5) Memanfaatkan sumber-sumber yang terbatas untuk kepentingan lingkungan dan sistem.

6) Penyesuaian budaya dan aspek lainnya sebagai hasil seleksi alamiah.

Dari batasan-batasan tersebut dapat disimpulkan bahwa adaptasi merupakan proses penyesuaian. Penyesuaian dari individu, kelompok, maupun unit sosial terhadap norma-norma, proses perubahan ataupun suatu kondisi yang diciptakan. Lebih lanjut tentang proses penyusuaian tersebut. Aminuddin menyebutkan bahwa penyesuaian dengan tujuan-tujuan tertentu, di antaranya:

1) Mengatasi halangan-halangan dari lingkungan.

2) Menyalurkan ketegangan sosial.

3) Mepertahankan kelanggengan kelompok atau unit sosial.

4) Bertahan hidup.

\subsection{Lansia}

\section{Definisi Lansia}

Lanjut usia (lansia) adalah bagian dari proses tumbuh kembang. Manusia tidak secara tibatiba menjadi tua, tetapi berkembang dari bayi, anakanak, dewasa, dan akhirnya menjadi tua. Aging process (proses penuaan merupakan suatu hal yang wajar, dan ini akan dialami oleh semua orang yang dikaruniai umur panjang, hanya cepat dan lambatnya proses tersebut tergantung pada masing-masing individu.

Menurut World Health Organisation (WHO), lansia adalah seseorang yang telah memasuki usia 60 tahun keatas. Lansia merupakan kelompok umur pada manusia yang telah memasuki tahapan akhir dari fase kehidupannya. Kelompok yang dikategorikan lansia ini akan terjadi suatu proses yang disebut Aging Process atau proses penuaan.

Proses penuaan adalah siklus kehidupan yang ditandai dengan tahapantahapan menurunnya berbagai fungsi organ tubuh, yang ditandai dengan semakin rentannya tubuh terhadap berbagai serangan penyakit yang dapat menyebabkan kematian misalnya pada sistem kardiovaskuler dan pembuluh darah, pernafasan, pencernaan, endokrin dan lain sebagainya. Hal tersebut disebabkan seiring meningkatnya usia sehingga terjadi perubahan dalam struktur dan fungsi sel, jaringan, serta sistem organ. Perubahan tersebut pada umumnya mengaruh pada kemunduran kesehatan fisik dan psikis yang pada akhirnya akan berpengaruh pada ekonomi dan sosial lansia. Sehingga secara umum akan berpengaruh pada activity of daily living (Fatmah, 2010)

\section{Batasan Lansia}

Batasan umur pada usia lanjut dari waktu ke waktu berbeda. Menurut World Health Organitation (WHO) lansia meliputi :

1) Usia pertengahan (middle age) antara usia 45 sampai 59 tahun

2) Lanjut usia (elderly) antara usia 60 sampai 74 tahun

3) Lanjut usia tua (old) antara usia 75 sampai 90 tahun

4) Usia sangat tua (very old) diatas usia 90 tahun

Berbeda dengan WHO, menurut Departemen Kesehatan RI (2006) pengelompokkan lansia menjadi :

1) Virilitas (prasenium) yaitu masa persiapan usia lanjut yang menampakkan kematangan jiwa (usia 55-59 tahun)

2) Usia lanjut dini (senescen) yaitu kelompok yang mulai memasuki masa usia lanjut dini (usia 60-64 tahun)

3) Lansia berisiko tinggi untuk menderita berbagai penyakit degeneratif (usia >65 tahun)

Batasan lansia menurut Levinson:

1) Lansia peralihan awal, antara 50-55 tahun.

2) Lansia peralihan menengah, antara 55-60 tahun.

3) Lansia peralihan akhir, antara 60-65 tahun.

\section{Tugas Perkembangan Lansia}

Tugas perkembangan lansia lebih banyak berkaitan dengan kehidupan pribadi seseorang dari pada orang lain (Hurlock, 2006). Adapun tugas perkembangan lansia adalah:

1) Menyesuaikan diri dengan menurunnya kekuataan fisik dan kesehataan.

2) Menyesuaikan diri dengan masa pensiun dan berkurangnya penghasilan keluuarga.

3) Menyesuaikan diri dengan kematian pasangan hidup.

4) Membentuk hubungan dengan orang-orang seusia.

5) Membentuk pengaturan kehidupan fisik yang memuaskan. 
6) Menyesuaikan dengan sosial secara luwes.

\section{Perubahan-perubahan Yang Terjadi Pada Lansia}

Perubahan yang terjadi pada lanjut usia (Hutapea, 2005) meliputi :

1) Perubahan fisik

a. Perubahan pada system kekebalan atau imunologi dimana tubuh menjadi rentan terhadap penyakit dan alergi.

b. Konsumsi energik turun secara nyata diikuti dengan menurunnya jumlah energi yang dikeluarkan tubuh.

c. Air didalam tubuh turun secara signifikan karena bertambahnya sel-sel mati yang diganti lemak.

d. Sistem pencernaan mulai terganggu, gigi mulai tanggal, kemampuan mencerna makan serta penyerapan menjadi lambat dan kurang efisien, gerakan peristaltik usus menurun sehingga sering konstipasi.

e. Sistem syaraf menurun yang menyebabkan munculnya rabun dekat kepekaan bau dan rasa berkurang, kepekaan sentuhan berkurang. Reaksi menjadi lambat, fungsi mental menurun dan ingatan visual berkurang.

f. Perubahan pada system pernafasan ditandai dengan menurunnya elastisitas paru-paru yang mempersulit pernafasaan sehingga dapat mengakibatkan munculnya rasa sesak dan tekanan darah meningkat.

g. Perubahan system metabolik, yang menyebabkan gangguan metabolisme glukosa karena sekresi juga menurun karena timbulnya lemak.

\section{2) Perubahan psikososial}

Perubahan psikososial menyebabkan rasa tidak aman, takut, merasa penyakit selalu mengancam, sering bingung, panik dan depresi. Hal itu disebabkan antara lain karena ketergantungan sosial finansial pada waktu pensiun menyebabkan kehilangan rasa bangga, hubungan sosial, kewibawaan dan sebagainya.

3) Perubahan emosi dan kepribadian

Setiap ada kesempatan lanjut usia selalu melakukan instropeksi diri. Terjadi proses kematangan dan bahkan tidak jarang terjadi pemeranan gender yang terbalik. Para wanita lansia bisa lebih tegar dibandingkan lansia pria, apalagi dalam memperjuangkan hak mereka. Sebaliknya, banyak lansia pria, apalagi dalam memperjuangkan hak mereka. Sebaliknya, banyak lanjut usia pria yang tidak segan-segan memerankan peran yang sering wanita kerjakan, seperti mengasuh cucu, menyiapkan sarapan, membersihkan rumah dan sebagainya. Persepsi tentang kondisi kesehatan berpengaruh kepada kehidupan psikososial, dalam hal memilih bidang kegiatan yang sesuai dan cara menghadapi persoalan hidup. Perubahan-perubahan

\section{Tipe-tipe Lansia}

Penggolongan lanjut usia menurut Nugroho, 2000 dalam Lilik Ma'rifatul Azizah (2011:4) dibagi menjadi 2 golongan, yaitu:

a. Serat Werdatama (Mangun Negoro IV)

1) Wong sepuh yaitu orang tua yang sepi hawa nafsu, mengetahui ilmu "dwi tunggal”, yakni mampu membedakan baik buruk, antara sajati dan palsu dan antara Gusti (Tuhan) dan kawulanya.

2) Tua sepah yaitu orang tua yang kosong, tidak tahu rasa, bicaranya muluk- muluk tanpa isi, tingkah lakunya dibuat-buat dan berlebihlebihan serta memalukan.

\section{b. Serat Kalatida (Ronggo Warsito)}

1) Orang yang berbudi sentosa yaitu orang tua yang meskipun diridhoi Tuhan dengan riski, namun tetap berusaha ingat dan waspada.

2) Orang lemah yaitu orang tua yang berputus asa, sudah tua mau apa, sebaiknya hanya menjauhkan diri keduniawian, supaya mendapat kasih

Tipe kepribadian lanjut usia menurut Kuntjoro 2002 dalam Lilik Ma'rifatul Azizah (2011:4) sebagai berikut:

1)Tipe kepribadian konstruktif (contstruction personality) yaitu orang yang memiliki integritas baik, menikmati hidupnya, toleransi tinggi dan fleksibel. Biasanya tipe ini tidak banyak mengalami gejolak, tenang dan mantap sampai sangat tua. Tipe kepribadian ini biasanya dimulai dari masa mudanya. Lansia bisa menerima fakta proses menua dan menghadapi masa pensiun dengan bijaksana dan menghadapi kematian dengan penuh kesiapan fisik dan mental. 
2)Tipe kepribadian mandiri (independent personality) yaitu orang yang mempunyai kecenderungan mengalami post power sindrome, apalagi pada masa lansia tidak diisi dengan kegiatan yang dapat memberikan otonomi.

3)Tipe kepribadian tergantung (dependent personality) yaitu orang yang biasanya sangat dipengaruhi kehidupan keluarga, apabila kehidupan keluarga selalu harmonis pada masa lansia tidak bergejolak, tetapi jika pasangan hidup meninggal maka pasangan yang ditinggalkan akan menjadi sedih yang mendalam. Tipe ini lansia senang mengalami pensiun, tidak punya inisiatif, pasif tetapi masih tahu diri dan masih dapat diterima oleh masyarakat.

4)Tipe kepribadian bermusuhan (hostile personality) yaitu orang yang setelah memasuki lansia tetap merasa tidak puas dengan kehidupannya, banyak keinginan yang tidak diperhitungkan sehingga menyebabkan kondisi ekonominya menurun. Mereka menganggap orang lain menyebabkan kegagalan, selalu mengeluh dan curiga. Menjadi tua tidak ada yang dianggap baik, takut mati dan iri hati pada yang muda.

5)Tipe kepribadian defensive yaitu tipe orang yang selalu menolak bantuan, emosinya tidak terkontrol, bersifat kompulsif aktif. Mereka takut menjadi tua dan tidak menyenangi masa pensiun.

6)Tipe kepribadian kritik diri (self hate personality) yaitu orang yang biasanya terlihat sengsara, karena perilakunya sendiri sulit dibantu orang lain atau cenderung membuat susah dirinya. Selalu menyalahkan diri, tidak mempunyai ambisi dan merasa korban dari keadaan.

\subsection{Panti Werdha}

Menurut Kamus Besar Bahasa Indonesia (2005,826): arti dari kata panti werdha adalah rumah tempat mengurus dan merawat orang jompo. Sedangkan menurut Kepala PSTW Yogyakarta Unit Budhi Luhur, Sutiknar pada seminar peningkatan kualitas sumber daya manusia melalui brain development di Jakarta, Selasa (6/12), panti sosial tresna werdha adalah panti sosial yang mempunyai tugas memberikan bimbingan dan pelayanan bagi lansia terlantar agar dapat hidup secara baik dan terawat dalam kehidupan masyarakat baik yang berada di dalam panti maupun yang berada di luar panti. (Tata Laksana Usia Lanjut di Panti Jompo, 2011:3).

\section{Fungsi dan Tujuan Panti Werdha}

Secara umum, Panti Sosial Tresna Werdha atau Panti werdha mempunyai fungsi sebagai berikut (Herwijayanti, 1997) :

1) Sebagai tempat untuk menampung manusia lanjut usia yang menyediakan fasilitas dan aktifitas khusus untuk manula yang dijaga dan dirawat oleh suster atau pekerja sosial (Murti, 2013).

2) Pusat pelayanan kesejahteraan lanjut usia dalam memenuhi kebutuhan pokok lansia dengan sistem penyantunan di dalam panti;

3) Menyediakan suatu wadah berupa kompleks bangunan dan memberikan kesempatan pula bagi lansia melakukan aktivitas-aktivitas sosial-rekreas serta membuat lansia dapat menjalani proses penuaannya dengan sehat dan mandiri.

Sesuai dengan permasalahan lansia, pada umumnya penyelenggaraan Panti Werdha mempunyai tujuan antara lain (Departemen Sosial RI, 1997) :

1) Untuk menampung manusia lanjut usia dalam kondisi sehat dan mandiri yang tidak memiliki tempat tinggal dan keluarga atau yang memiliki keluarga namun dititipkan karena ketidakmampuan keluarga untuk merawat manula (Murti, 2013).

2) Agar terpenuhi kebutuhan hidup lansia;

3) Agar dihari tuanya dalam keadaan tentram lahir dan batin.

4) Dapat menjalani proses penuaannya dengan sehat dan mandiri.

\subsection{Pelayanan dan Kebijakan Panti Werdha Terhadap Lansia}

\section{Pelayanan yang Diberikan Panti Werdha}

Merujuk pada Peraturan Menteri Sosial No. 19 tahun 2012 tentang Pedoman Pelayanan Sosial Lanjut Usia, pada pasal 7 tercantum bahwa pelayanan dalam panti dilakukan dengan tujuan untuk meningkatkan kualitas hidup, kesejahteraan, dan terpenuhinya kebutuhan dasar lanjut usia. Adapun jenis pelayanan yang diberikan dalam panti, meliputi:

1) Tempat tinggal yang layak bagi lansia adalah yang bersih, sehat, aman, nyaman, dan memiliki akses yang mudah pada fasilitas yang dibutuhkan lansia, sehingga dengan kondisi kemampuan fisiknya yang makin menurun masih memungkinkan dapat menjalankan aktivitas sehari-hari dengan mudah, aman, dan tidak sangat tergantung pada orang lain. Umumnya lanjut usia dihadapkan pada masalah 
hunian sebagai berikut: lokasi kamar yang berjauhan dengan lokasi kamar mandi, keadaan kamar mandi yang kurang mendukung, penggunaan tangga, permukaan lantai yang tidak rata, dan alur sirkulasi hunian terhadap fasilitas lingkungan kurang menunjang. Tempat tinggal yang layak bagi lansia adalah yang lapang atau barrier free. Hal ini sangat bermanfaat bagi lansia, terutama dalam pergerakan atau aksesibilitas dalam rumah, bahkan ketika mereka harus menggunakan kursi roda. Kurniadi (2012) merinci karakterik rumah yang ramah lansia, secara garis besar, terbebas dari tangga dan lantai yang tidak rata atau licin, pencahayaan yang baik, kamar mandi dekat dengan kamar dan memungkinkan kursi roda dapat masuk, dan aman karena mereka kurang mampu melindungi dirinya terhadap bahaya. Di negara-negara maju, pelayanan kelompok lanjut usia dilakukan dalam ruangan khusus, bahkan rumah sakit khusus dan perkampungan khusus. Adanya fasilitas tersebut ditujukan untuk memberi lingkungan kehidupan yang nyaman dan sesuai bagi kelompok lanjut usia (Wijayanti, 2008). Kondisi hunian di dalam panti pun seyogyanya memperhatikan kebutuhan lansia tersebut.

2) Para lansia seyogyanya mendapatkan makanan yang sesuai dengan kondisi kesehatannya. Oleh karena itu, makanan untuk lansia sebaiknya dikontrol atas rekomendasi ahli gizi. Ahli gizi perlu berkerjasama dengan dokter untuk mengetahui kondisi kesehatan lansia atau jenis penyakit yang diderita, untuk menentukan apa yang boleh atau tidak boleh dimakan. Dengan demikian, makanan untuk masing-masing lansia kemungkinan berbeda dengan cara mengolah yang berbeda pula. Pakaian yang digunakan sebaiknya bersih, layak dan nyaman dipakai. Untuk pemeliharaan kesehatan seyogyanya terdapat fasilitas kesehatan berupa poliklinik yang buka 24 jam dan memberikan pelayanan kegawatdaruratan yang mudah diakses. Apabila perlu dirujuk, tersedia fasilitas ambulans yang siap setiap saat. Biasanya diperlukan pula fasilitas fisioterapi.

3) Pemanfaatan waktu luang merupakan suatu upaya untuk memberikan peluang dan kesempatan bagi lansia untuk mengisi waktu luangnya dengan berbagai kegiatan atau aktivitas yang positif, bermakna, dan produktif bagi dirinya maupun orang lain.
Kegiatan-kegiatan yang mereka lakukan harus sesuai dengan minat, bakat, dan potensi yang mereka miliki (Annubawati, 2014). Tidak hanya sekedar mengisi waktu luang tetapi sesuatu yang menyenangkan, akan lebih baik jika produktif; sehingga dapat berfungsi sebagai terapi masalah psikososial dan emosional yang mungkin dialami oleh lansia. Demikian juga dengan kegiatan rekreasi, seyogyanya tidak hanya menyenangkan tetapi merupakan kesempatan untuk berinteraksi dengan lingkungan di luar panti sehingga mereka merasa tidak terisolasi tetapi masih terhubung dengan lingkungan di sekitarnya.

4) Bimbingan mental dan agama lebih ditujukan untuk mengatasi masalah emosional dan psikologis. Berdasarkan informasi dari Tim Kajian Bentuk Pelayanan Lanjut Usia di Daerah Istimewa Yogyakarta, banyak lansia yang tinggal di panti werdha yang kesepian, sedih, menarik diri dari pergaulan dan kegiatan, pasif, murung, mengalami emosi negatif, bermusuhan dengan sesama penghuni panti, dan sebagainya. Untuk membantu mengatasi masalah tersebut kegiatan bimbingan mental dan keagamaan melalui kegiatan konseling dapat membantu mereka. Sementara itu, bimbingan sosial lebih ditujukan untuk mengatasi masalah relasi sosial dengan keluarga atau lingkungan sosialnya. Terkait dengan pelaksanaan bimbingan sosial di panti wedha, Tim Kajian Bentuk Pelayanan Lansia di DIY (2014) menemukan bahwa di panti werdha ada kecenderungan pelayanan bimbingan sosial ini relatif sama dengan bimbingan psikologis; belum diarahkan untuk memfasilitasi interaksi atau komunikasi antar penghuni panti sosial maupun dengan warga masyarakat lainnya. Masalah relasi sosial seringkali menjadi penyebab atau saling pengaruh mempengaruhi dengan masalah emosional dan psikologis, sehingga memperbaiki relasi sosial dengan keluarga atau lingkungan sosial lainnya akan membantu memecahkan masalah emosional dan psikologis juga.

5) Pelayanan bagi lansia dalam panti diberikan sampai dengan lansia meninggal. Pelayanan yang diberikan merupakan perawatan jangka panjang (Long-Term Care). Oleh karena itu, pelayanan pengurusan pemakaman pun turut menjadi 
tanggung jawab panti, sesuai dengan agama yang dianutnya masing-masing.

\section{Kebijakan dalam Pelayanan Lansia}

Menurut Undang-undang nomor 13 tahun 1998 pasal 3 tentang kesejahteraan sosial menyatakan bahwa upaya meningkatkan kesejahteraan sosial lanjut usia meliputi pelaksanaan pelayanan bimbingan fisik, pelayanan bimbingan keagamaan/ mental spiritual, pelayanan bimbingan sosial dan bimbingan keterampilan.

\section{1) Pelayanan Bimbingan Fisik}

Pelayanan bimbingan fisik merupakan serangkaian kegiatan yang bertujuan untuk memelihara dan meningkatkan derajat kesehatan dan kemampuan lanjut usia agar kondisi fisik, mental dan sosialnya dapat berfungsi secara wajar. Pelayanan bimbingan fisik dapat berupa penyediaan menu makanan tambahan sesuai dengan kalori yang dibutuhkan, kegiatan olahraga/ kebugaran yang dilakukan setiap pagi.

2) Pelayanan Bimbingan Keagamaan/ Mental Spiritual

Pelayanan bimbingan keagamaan/ mental spiritual merupakan serangkaian kegiatan yang bertujuan untuk meningkatkan di ikuti dengan kegiatan peningkatan iman dan ketakwaan kepada Tuhan Yang Maha Esa. Agama dapat menjadi landasan perilaku seseorang apabila seseorang tersebut, mengerti, merasakan membiasakan dan mengamalkan ajaran agama. Oleh karena itu diperlukan adanya bimbingan keagamaan seharihari untuk melakukan perintah Allah dan menjauhi larangannya, menanamkan betapa pentingnya agama dalam kehidupan dan mengerti tujuan dari agama tersebut.

\section{3) Pelayanan Bimbingan Sosial}

Bimbingan sosial merupakan upaya untuk membantu individu dalam mengenal dan berhubungan dengan lingkungan sosial yang dilandasi dengan tanggungjawab. Menurut Mappiare (1982: 130) bimbingan sosial adalah upaya untuk membantu individu dalam menghadapi keadaan batinnya sendiri dan mengatasi konflikkonflik dalam diri dalam upaya mengatur dirinya sendiri di bidang kerohanian, perawatan jasmani, pengisian waktu luang dan sebagainya. Pelayanan bimbingan sosial diberikan dalam rangka menciptakan hubungan sosial secara serasi dan harmonis diantara lanjut usia, petugas, pimpinan lembaga dengan masyarakat. Petugas panti bersama pekerja sosial, relawan senantiasa memberikan support (dorongan) secara rutin dan terus menerus, sehingga diharapkan mereka dalam menghabiskan hari-hari tuanya di dalam panti mendapatkan ketentraman, kebahagiaan lahir dan batin.

\section{4) Pelayanan Bimbingan Keterampilan}

Pelayanan bimbingan keterampilan diberikan untuk mengisi waktu luang, meningkatkan produktivitas agar dapat menambah penghasilan, antara lain: peternakan, pertanian, keterampilan memijat, membuat barang-barang kerajinan dan lain-lain. Pelayanan keterampilan bagi lanjut usia potensial dimaksudkan untuk memberi peluang untuk mendayagunakan pengetahuan, keahlian, kemampuan, keterampilan, dan pengalaman yang dimilikinya.

\section{Simpulan}

Proses adaptasi bagi lansia di panti werdha bukanlah suatu hal yang mudah, mengingat setiap lansia memiliki sifat dan perilaku yang berbeda. Oleh karena itu dibutuhkan keterlibatan dari berbagai pihak untuk membantu proses adaptasi tersebut, dan yang terutama adalah dari panti werdha itu sendiri.

Panti werdha dapat diibaratkan sebagai “rumah” bagi lansia. Oleh karena itu sebagaimana fungsinya, diharapkan panti werdha, selain digunakan sebagai tempat tinggal lansia, juga harus berfungsi sebagai tempat yang menyediakan pelayanan dan lingkungan yang sebaik mungkin bagi lansia. Pelayanan yang diberikan telah diatur dalam Undang-undang nomor 13 tahun 1998 pasal 3 tentang kesejahteraan sosial yang menyatakan bahwa upaya meningkatkan kesejahteraan sosial lanjut usia meliputi pelaksanaan pelayanan bimbingan fisik yang berkaitan dengan pemeliharaan kesehatan dan kondisi fisik lansia, pelayanan bimbingan keagamaan/ mental spiritual yang behubungan dengan kerohanian lansia, pelayanan bimbingan sosial untuk membantu lansia untuk berhubungan dengan lingkungan sosialnya, dan bimbingan keterampilan yang ditujukan agar lansia memiliki poduktivitas untuk mengisi waktu luangnya.

Dengan adanya kebijakan mengenai pelayanan tesebut, diharapkan panti werdha dapat menciptakan kondisi yang nyaman bagi lansia dan dapat membantu lansia tersebut untuk beradaptasi di lingkungannya yang baru.

\section{Daftar Pustaka}

A.S. Susanto. 1985. Pengantar Sosiologi Sosial,Bandung: PT Remaja Rosdakarya

Annisa, L. 2017. Statistis Penduduk Lanjut Usia 2017. Badan Pusat Statistik. 
Annubawati, E.A. 2014. Pengisian Waktu Luang bagi Lanjut Usia dengan Bimbingan Keterampilan. Melalui http://budhidharma.kemsos.go.id/modul es.php?name $=$ News\&file=article\&sid $=173$

Azizah, Lilik Ma’rifatul (2011). Keperawatan Lanjut Usia. Graha Ilmu. Yogyakarta.

Christanti, D.A., Santoso, M.B., dan Wibhawa, B. 2016. Asesmen Spiritualitas Dalam Praktik Pekerjaan Sosial (Studi Kasus Spiritualitas Lansia di Balai Perlindungan Sosial Tresna Werdha). Bandung: Unpad Press.

Darmawan, M. 2016. “Gambaran Tingkat Depresi Pada Lansia Yang Tinggal Di Panti Griya Sehat Bahagia Palur Karanganyar”. Skripsi. Fakultas Ilmu Kesehatan, Universitas Muhammadiyah Surakarta.

Fatmah . 2010. Gizi Usia Lanjut. Erlangga. Jakarta.

Hawari, Dadang. 2012. Pendekatan Holistic pada Gangguan Jiwa Skizofrenia. Jakarta : FKUI

Humaedi, S. dan Sulastri, S. 2017. Pelayanan Lanjut Usia Terlantar Dalam Panti. Prosiding KS: Riset \& PKM. Vol 4(1). 155-164.

Hurlock, E. B. 2006. Psikologi Perkembangan Suatu Pendekatan Sepanjang Rentang Kehidupan. Edisi kelima. Jakarta: Erlangga.

Hutapea, Ronald. 2005. Sehat dan Ceria Diusia Senja. PT Rhineka Cipta: Jakarta

Indarwati. 2014. "Peranan Pekerja Sosial Dalam Meningkatkan Kesejahteraan Sosial Lanjut Usia (Lansia) Di Unit Rehabilitasi Sosial Purbo Yuwono Brebes”. Skripsi. Fakultas
Ilmu Pendidikan, Universitas Negeri Semarang.

Murti, R. Indira. 2013. Perancangan Interior Pada Panti Jompo Melania Di Bandung. Thesis. Universitas Bina Nusantara. Jakarta.

Peraturan Menteri Sosial No. 19 tahun 2012 tentang Pedoman Pelayanan Sosial Lanjut Usia

Septiani, M. 2017. “Adaptasi Mahasiswa Papua Di Bandar Lampung (Studi Pada Mahasiswa asal Papua di Universitas Lampung)”. Skripsi. FISIP, Program Studi Ilmu Komunikasi, Universitas Lampung.

Suryo, H. 2011. "Gambaran Depresi Pada Lansia Di Panti Wredha Dharma Bhakti Surakarta”. Skripsi. Fakultas Ilmu Kesehatan, Universitas Muhammadiyah Surakarta.

Undang-Undang Nomor 13 Tahun 1998 Tentang Kesejahteraan Lanjut Usia

W. A. Gerungan. 1996. Psikologi Sosial. Bandung: Eresco.

Wijayanti. 2008. "Hubungan Kondisi Fisik RTT Lansia Terhadap Kondisi Sosial Lansia di RW 03 RT 05 Kelurahan Tegalsari, Kecamatan Candisari”. ENCLOSURE Volume 7 No. 1 Maret 2008 hlm. 38-49 Jurnal Ilmiah Perancangan Kota dan Permukiman. Melalui http://eprints.undip.ac.id/20145/1/5.p df

Winata, A. 2014. “Adaptasi Sosial Mahasiswa Rantau Dalam Mencapai Prestasi Akademik”. Skripsi. FISIP, Program Studi Ilmu Kesejahteraan Sosial, Universitas Bengkulu. 